\title{
The inactive $X$ chromosome in the human female is enriched in 5-methylcytosine to an unusual degree and appears to contain more of this modified nucleotide than the remainder of the genome
}

\author{
DEEPTI D. DEOBAGKAR ${ }^{1,3}$ and H. SHARAT CHANDRA ${ }^{2,3}$ \\ ${ }^{1}$ Department of Zoology, University of Pune, Pune 411 007, India \\ ${ }^{2}$ Centre for Human Genetics, G-04, ITPL, Whitefield, Bangalore 560 066, India \\ ${ }^{3}$ Department of Microbiology and Cell Biology, Indian Institute of Science, Bangalore 560 012, India
}

\begin{abstract}
By employing a procedure that combines ELISA and photoacoustic spectroscopy, we have examined the content of 5-methylcytosine $\left(\mathrm{m}^{5} \mathrm{C}\right)$ in DNA of individuals who differed from one another in the number of $\mathrm{X}$ chromosomes in their genomes. The results show that the human inactive $\mathrm{X}$ chromosome (Xi) contains very high amounts of this modified nucleotide. We estimate that in the $46, \mathrm{XX}$ female there is more $\mathrm{m}^{5} \mathrm{C}$ in $\mathrm{Xi}\left(\sim 3.6 \times 10^{7}\right)$ than in all the remaining chromosomes put together $\left(\sim 2.1 \times 10^{7}\right)$. Our results also suggest that nearly one-fifth of all cytosines in Xi are methylated and that, in addition to $\mathrm{CpG}$ methylation, there is extensive non-CpG methylation as well.
\end{abstract}

[Deobagkar D. D. and Chandra H. S. 2003 The inactive X chromosome in the human female is enriched in 5-methylcytosine to an unusual degree and appears to contain more of this modified nucleotide than the remainder of the genome. J. Genet. 82, 13-16]

\section{Introduction}

The hypothesis that methylation of cytosine residues in DNA is a key step in the maintenance of the inactive state of the mammalian $\mathrm{X}$ chromosome (Holliday and Pugh 1975; Riggs 1975) has found support from several types of experiment (Liskay and Evans 1980; Mohandas et al. 1981). But there are no data on the amount of 5methylcytosine $\left(\mathrm{m}^{5} \mathrm{C}\right)$ in the inactive $\mathrm{X}$ chromosome (Xi). A combination of ELISA and photoacoustic spectroscopy (PAS) provides a means of estimating the genomic content of $\mathrm{m}^{5} \mathrm{C}$ irrespective of the sequence context in which the modified nucleotide occurs (Achwal and Chandra 1982; Achwal et al. 1984). We have previously used this method to measure the very small amounts of $\mathrm{m}^{5} \mathrm{C}$ present in Drosophila melanogaster DNA (Achwal et al. 1984) and these observations have been confirmed by direct sequencing (Lyko et al. 2000) and dinucleotide analysis (Gowher et al. 2000). In this paper we report on

For correspondence, e-mail: dddeo@unipune.ernet.in, sharat@mcbl. iisc.ernet.in. experiments aimed at estimating the content of $\mathrm{m}^{5} \mathrm{C}$ in the human inactive $X$ chromosome by application of the ELISA-PAS method to samples of genomic DNA from individuals whose karyotypes differed from one another in the number of $\mathrm{X}$ chromosomes $(45, \mathrm{XO} ; 46, \mathrm{XX}$; 47,XXX and 48,XXXX).

\section{Materials and methods}

DNA was isolated from lymphocytes or cultured fibroblasts of seven women and from cultured fibroblasts of a female foetus. Details of these sources are given below.

(i) 45, AAXO (Turner syndrome patient \#1); female, Indian; lymphocytes

(ii) 45,AAXO (Turner patient \#2); female, Indian; lymphocytes

(iii) 45,AAXO (GM 775); fibroblast culture derived from a Caucasian Turner patient; at the time of isolation of DNA, these cells were in serial passage number 15 (iv) 46, AAXX (MRC-9, ATCC CCL 212); fibroblastlike cell line derived from normal lung tissue of a

Keywords. 5-methylcytosine; $\mathrm{X}$ inactivation; human $\mathrm{X}$ chromosome; methylation; photoacoustic spectroscopy. 
15-week-old female foetus of Caucasian parents; this line was reported, at the time of this study, to stably maintain a diploid karyotype with a stemline number of 46 chromosomes (passage number 28)

(v) 46,AAXX; female, Indian; lymphocytes

(vi) 46,AAXX; female, Indian; lymphocytes

(vii) 47,AAXXX (GM 254); fibroblast culture derived from a Caucasian female; no chromosomal mosaicism was reported (passage number 10)

(viii) 48,AAXXXX (GM 1415); fibroblast culture derived from a Caucasian female; the culture was reported to have $4 \%$ polyploid cells (passage number 9 ).

Peripheral blood from individuals (i), (ii), (v) and (vi) was kindly provided by Dr Manorama Thomas, St John's Medical College, Bangalore. The fibroblast cell lines GM 775, GM 254 and GM 1415 were obtained from the Human Mutant Cell Repository (Camden, USA). The diploid cell line MRC-9, ATCC CCL 212 was obtained from the National Institute of Virology, Pune, India. There was no evidence of chromosomal mosaicism among the sampled cells in these eight cases. 'Unmethylated' DNA from bacteriophage lambda grown in $\mathrm{dcm}^{-}$, $\mathrm{dam}^{-}$E. coli served as negative control and DNA from the mealybug Planococcus lilacinus, which has approximately $1.8 \mathrm{~mol} \% \mathrm{~m}^{5} \mathrm{C}$ in its genome (Deobagkar et al. 1982), served as positive control. DNA from the bacteriophage $\phi X 174$, which contains one $\mathrm{m}^{5} \mathrm{C}$ residue in its genome of 5386 nucleotides (Sanger et al. 1978), was used for calibration. The methods by which the polyclonal anti- $\mathrm{m}^{5} \mathrm{C}$ antibody used in this study was prepared and characterized $\left(K_{\mathrm{a}}\right.$ of $\left.1.56 \times 10^{9} \mathrm{M}^{-1}\right)$ have been described earlier (Achwal and Chandra 1982; Achwal et al. 1984). Identical amounts of DNA (six nanograms from each individual) were spotted on nitrocellulose membrane (BA 85 from $\mathrm{S} \& \mathrm{~S}$ or an equivalent product from Advanced Microdevices, Ambala, India), treated with anti- $\mathrm{m}^{5} \mathrm{C}$ antibody, and processed as described (Achwal and Chandra 1982). The $\mathrm{m}^{5} \mathrm{C}$-antibody-DNA complex was treated with biotin-avidin-peroxidase and stained by using $0.1 \%$ DABT and $0.02 \% \mathrm{H}_{2} \mathrm{O}_{2}$. The staining intensity was measured at $520 \mathrm{~nm}$ in a photoacoustic spectrometer. This instrument, built by Ganguly and Rao (1981), had been fitted with a $200 \mathrm{~W}$ tungsten lamp. The chopping frequency was $23 \mathrm{~Hz}$. The PA signal intensity of each spot of DNA was measured thrice and the average value was calculated.

The numbers of cytosine residues and $\mathrm{CpG}$ dinucleotides in the $\mathrm{X}$ chromosome were calculated from the human genome sequence database (ftp://ftp.ensembl.org/pub/ current_human/data/golden_path/).

\section{Results and discussion}

Although each spot contained the same amount of DNA, it was clear from visual inspection itself that the staining intensity increased with the number of $\mathrm{X}$ chromosomes in the genome, in the order: AAXO $<$ AAXX $<$ AAXXX $<$ AAXXXX (figure 1). The contrast between XO DNA and XX DNA was particularly clear. The staining intensities of these spots as recorded by PAS are given in table 1 . The relationship between the number of $\mathrm{X}$ chromosomes in the genome and $\mathrm{m}^{5} \mathrm{C}$ content was linear (figure 2). Since $\mathrm{X}$ chromosomes in excess of one are inactive, these data indicate that the $\mathrm{m}^{5} \mathrm{C}$ content of $\mathrm{Xi}$ is very high. The amount of $\mathrm{m}^{5} \mathrm{C}$ in the inactive $\mathrm{X}$ chromosome was estimated in the following manner. The PA signal intensity of XO DNA was $0.27 \pm 0.05$ units (table 1). Measured against the $\phi X 174$ calibration plot, this value corresponds to $\sim 56.25 \mathrm{ng}$ of $\phi \mathrm{X} 174 \mathrm{DNA}$ (figure 3 ). This amount of $\phi X 174$ DNA is expected to contain $1.98 \times 10^{10} \mathrm{~m}^{5} \mathrm{C}$ residues because there is a single $\mathrm{m}^{5} \mathrm{C}$ residue in the 5386 nucleotides that constitute the genome of this phage. Since $6 \mathrm{ng}$ of XO DNA would contain roughly 932 copies of the human genome, we estimate that the $45, \mathrm{XO}$ genome contains approximately $2.1 \times 10^{7} \mathrm{~m}^{5} \mathrm{C}$ residues (table 1).

The signal intensity of $6 \mathrm{ng}$ of $\mathrm{XX}$ DNA was more than twice the signal intensity of the same amount of XO DNA (table 1). It required $142.5 \mathrm{ng}$ of $\phi X 174$ DNA to give a signal equivalent to that of $6 \mathrm{ng}$ of human $\mathrm{XX}$ DNA (figure 3 ). This amount of $\phi X 174$ DNA is expected to contain about $0.49 \times 10^{11}$ residues of $\mathrm{m}^{5} \mathrm{C}$. On the assumption that in $6 \mathrm{ng}$ of human 46,XX DNA there are roughly 910 copies of the genome, we estimate that there are approximately $5.4 \times 10^{7} \mathrm{~m}^{5} \mathrm{C}$ residues in the genome of the human XX female.

The average PA signal intensity attributable to each inactive $\mathrm{X}$ was calculated by dividing the sum of the pairwise signal intensity differences $(\mathrm{XX}-\mathrm{XO}),(\mathrm{XXX}$ $-\mathrm{XO}$ ) and (XXXX-XO) by six, the number of inactive $\mathrm{X}$ chromosomes in these four genomes. This value turns out to be 0.445 (table 1 ), which is very similar to that

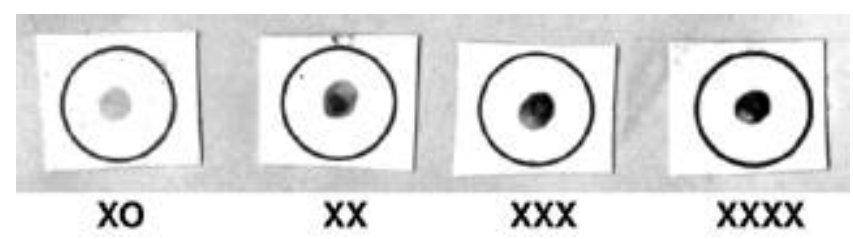

Figure 1. Staining intensities of samples of genomic DNA from individuals who differed from one another in the number of $\mathrm{X}$ chromosomes. Identical amounts $(6 \mathrm{ng})$ of DNA were spotted on nitrocellulose membrane, treated with anti- $\mathrm{m}^{5} \mathrm{C}$ antibody, and stained by avidin-peroxidase. All DNA samples were processed simultaneously on the same nitrocellulose membrane and the individual spots of DNA were then cut out for measurement of staining intensity in a photoacoustic spectrometer. As noted under Materials and methods, a $200 \mathrm{~W}$ tungsten filament lamp was used in the photoacoustic spectrometer. It may be possible to improve the sensitivity of this method substantially by the use of a $1000 \mathrm{~W}$ xenon arc lamp. 
Table 1. Estimation of $\mathrm{m}^{5} \mathrm{C}$ content by ELISA and photoacoustic spectroscopy.

\begin{tabular}{|c|c|c|c|c|c|}
\hline $\begin{array}{l}\text { Karyotype and } \\
\text { genome size }^{\mathrm{a}}\end{array}$ & Photoacoustic units ${ }^{b}$ & $\begin{array}{c}\text { No. of } \mathrm{m}^{5} \mathrm{C} \\
\text { residues }^{\mathrm{c}}\end{array}$ & $\begin{array}{l}\mathrm{m}^{5} \mathrm{C} \text { content } \\
\quad(\mathrm{mol} \%)^{\mathrm{c}}\end{array}$ & $\begin{array}{l}\text { No. of Cs } \\
\text { in } \mathrm{Xi}(\mathrm{s})^{\mathrm{d}}\end{array}$ & $\begin{array}{l}\text { No. of } \mathrm{CpGs} \\
\text { in } \mathrm{Xi}(\mathrm{s})^{\mathrm{d}}\end{array}$ \\
\hline $\begin{array}{l}45 \mathrm{AAXO} \\
6.44 \times 10^{9}\end{array}$ & $0.27 \pm 0.05$ & $2.05 \times 10^{7}$ & 0.38 & - & - \\
\hline $\begin{array}{l}46 \mathrm{AAXX} \\
6.6 \times 10^{9}\end{array}$ & $0.7 \pm 0.05$ & $5.46 \times 10^{7}$ & $0.83 *$ & $0.16 \times 10^{9}$ & $1.14 \times 10^{6}$ \\
\hline $\begin{array}{l}\text { 47AAXXX } \\
6.76 \times 10^{9}\end{array}$ & $1.18 \pm 0.05$ & $9.49 \times 10^{7}$ & 1.41 & $0.32 \times 10^{9}$ & $2.28 \times 10^{6}$ \\
\hline $\begin{array}{l}48 \mathrm{AAXXXX} \\
6.92 \times 10^{9}\end{array}$ & $1.6 \pm 0.05$ & $13.1 \times 10^{7}$ & 1.89 & $0.48 \times 10^{9}$ & $3.42 \times 10^{6}$ \\
\hline Average value per $\mathrm{Xi}$ & 0.445 & $3.64 \times 10^{7}$ & 0.53 & - & - \\
\hline
\end{tabular}

(a) $\mathrm{A}=$ one set of autosomes; $\mathrm{X}=$ one $\mathrm{X}$ chromosome. The genome size (number of nucleotides) was calculated from the human genome database (ftp://ftp.ensembl.org/pub/current_human/data/golden_path/). It is expected that in the XX, XXX and XXXX genomes the amount of autosomal and active-X DNA is the same as in the XO genome whereas both the amount and the proportion of inactive-X DNA would increase with genome size.

(b) The sign ' \pm ' refers to the extent of variation among (i) individual measurements in the XXX and XXXX cases and (ii) the averages of the measurements from different individuals in the XO and XX cases. Within the XO and XX chromosomal classes, the PA signal intensities of lymphocyte DNA and fibroblast DNA were similar.

(c) The calibration plot of the relationship between PA signal intensity and amount of $\phi X 174$ DNA (figure 3) was used to obtain these values. The procedure followed is described under Results and discussion.

(d) Calculated from total X-chromosome sequence data (ftp://ftp.ensembl.org/pub/current_human/data/golden_path/) by using the EMBOSS program (Rice et al. 2000).

*In an earlier publication (Achwal et al. 1984), our estimate of the amount of cytosine methylation in human DNA on the basis of ELISA-PAS measurements contains an error. The PA signal value of human DNA in table 1 of that paper should have been 0.5 units and not 1.5 units; consequently, the mol\% $\mathrm{m}^{5} \mathrm{C}$ content as estimated from the corrected value turns out to be about 0.7 , which is close to the value reported here.

obtained by dividing by three the sum of the pairwise differences (XX - XO), (XXX - XX) and (XXXX - XXX). From this value, following the same procedure as that outlined above for $\mathrm{XO}$ and $\mathrm{XX}$ DNA, we obtain $\sim 3.64 \times 10^{7}$ as the number of $\mathrm{m}^{5} \mathrm{C}$ residues in a single inactive $\mathrm{X}$ chromosome (figure 3 and table 1). This observation suggests that the amount of cytosine methylation in a single inactive $\mathrm{X}$ chromosome is higher than that in the entire 45,XO genome.

On the basis of dinucleotide analysis, it has been reported that a majority of $\mathrm{m}^{5} \mathrm{C}$ residues in human DNA are not in the $\mathrm{CpG}$ dinucleotide (Woodcock et al. 1987), but more recent reports suggest that most methylated cytosines occur in $\mathrm{CpG}$ dinucleotides (reviewed in Cross and Bird 1995). Analysis of the human genome sequence database shows that the $\mathrm{X}$ chromosome contains $\sim 1.6 \times$ $10^{8}$ cytosines and $\sim 1.14 \times 10^{6} \mathrm{CpG}$ dinucleotides (table 1 ). This observation, when viewed in light of our estimate of the number of $\mathrm{m}^{5} \mathrm{C}$ residues in $\mathrm{Xi}$, suggests that in the inactive $\mathrm{X}$ roughly one in every five cytosines is methylated, and that over $90 \%$ of the $\mathrm{m}^{5} \mathrm{C}$ residues occur in dinucleotides other than $\mathrm{CpG}$.

What relationship does such a high level of cytosine methylation have to the spread and maintenance of the $\mathrm{X}$ inactivation process? Answers to this question may be forthcoming if, by direct sequencing or other methods,

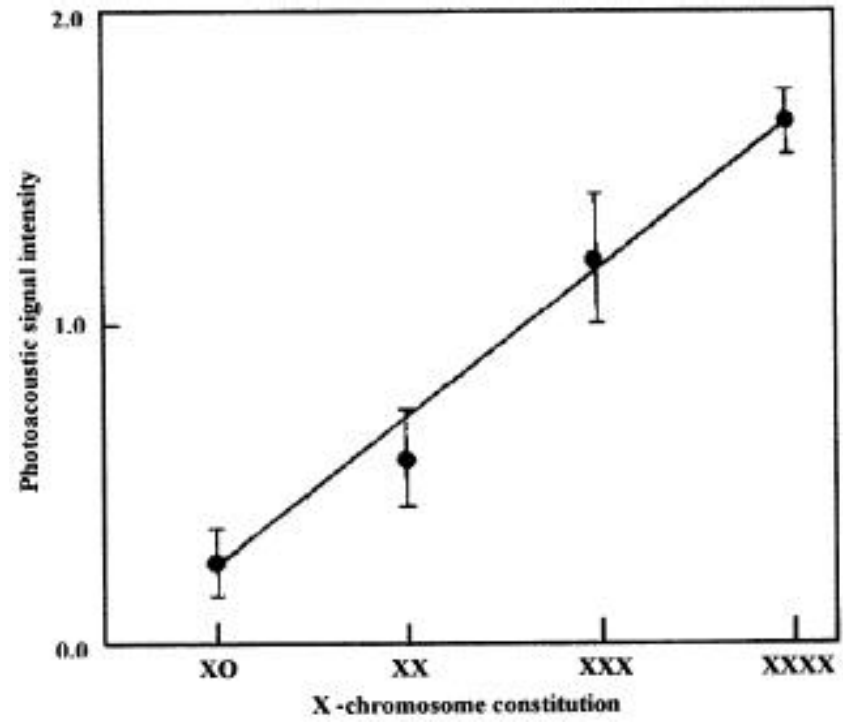

Figure 2. Photoacoustic signal intensities of the DNA samples [(PA signal intensity of spotted DNA) - (PA signal intensity of background)] plotted against the X-chromosome constitution of the individuals studied. The PA values used to prepare this plot are the same as those shown in table 1. See footnotes to table 1 for additional details. The average PA signal intensity of DNA samples from two 46,XY males was slightly higher (data not shown) than that of the XO samples, and significantly lower than that of the XX samples.. 


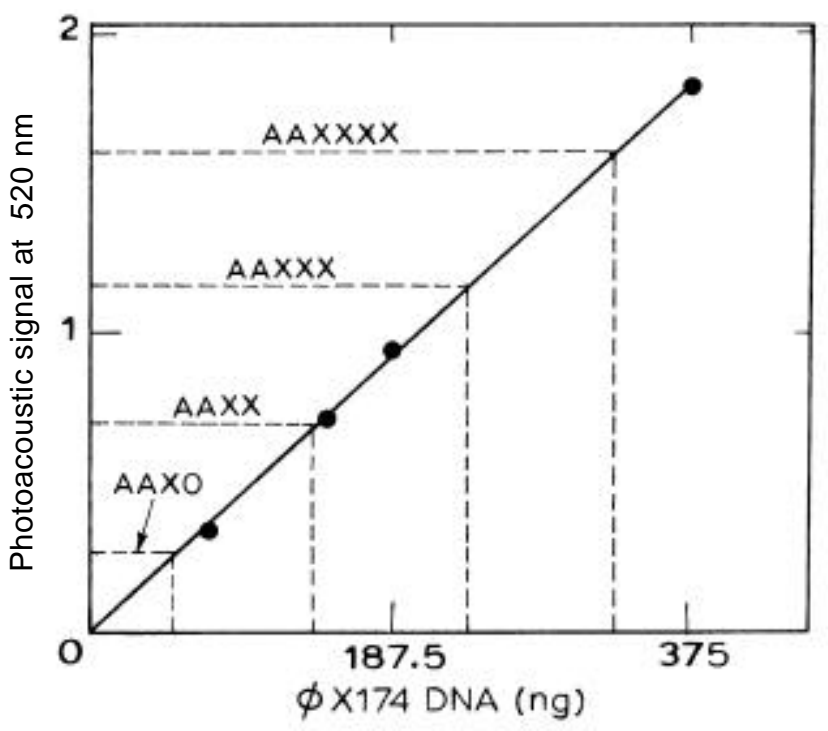

Figure 3. Intensity of photoacoustic signal ( $\left.I_{\text {spot }}-I_{\text {background }}\right)$ plotted against increasing amounts of $\phi X 174$ DNA (dark circles). Superimposed on the Y-axis are the PA values (figure 2 and table 1) of $6 \mathrm{ng}$ of DNA from AAXO, AAXX, AAXXX and AAXXXX individuals (broken lines). For the PA values of each of the human DNA examples, the amount of $\phi X 174$ DNA that gave an equivalent PA signal was noted (X-axis). These data were then used to estimate the amount of $\mathrm{m}^{5} \mathrm{C}$ in the human DNA samples as described under Results and discussion.

comparisons could be made between the distribution of $\mathrm{m}^{5} \mathrm{C}$ residues in homologous sequences in active and inactive $\mathrm{X}$ chromosomes and between regions of the $\mathrm{X}$ chromosome that are subject to inactivation and those that are not.

\section{Acknowledgements}

We thank C. N. R. Rao and P. Ganguly for advice on photoacoustic spectroscopy and access to the photoacoustic spectrometer, Raghubir Athwal and Suresh Jhanwar for assistance in obtaining some of the multiple-X cell lines, Manorama Thomas for the blood samples, T. M. Jacob and Dileep Deobagkar for advice on immunochemical procedures, N. V. Joshi for critical review, and K. Naga Mohan for useful suggestions. The Jawaharlal Nehru Centre for Advanced Scientific Research, Banga- lore, provided a fellowship to the first author to enable her to complete a part of this study. This work was supported by the Indian Council of Medical Research and the Department of Biotechnology, Government of India.

\section{References}

Achwal C. W. and Chandra H. S. 1982 A sensitive method for detecting 5mC in DNA fragments. FEBS Lett. 150, 469-472.

Achwal C. W., Ganguly P. and Chandra H. S. 1984 Estimation of the amount of 5-methlycytosine in Drosophila melanogaster DNA by amplified ELISA and photoacoustic spectroscopy. EMBO J. 3, 263-266.

Cross S. H. and Bird A. P. $1995 \mathrm{CpG}$ islands and genes. Curr. Opin. Genet. Dev. 5, 309-314.

Deobagkar D. N., Muralidharan K., Devare S. G., Kalghatgi K. and Chandra H. S. 1982 The mealybug chromosome system. I: unusual methylated bases and dinucleotides in DNA of a Planococcus species. J. Biosci. 4, 513-526.

Ganguly P. and Rao C. N. R. 1981 Photoacoustic spectroscopy of solids and surfaces. Proc. Indian Acad. Sci. (Chem. Sci.) 90, 153-214.

Gowher H., Leissman O. and Jeltsch A. 2000 DNA of Drosophila melanogaster contains 5mC. EMBO J. 19, 6918-6923.

Holliday R and Pugh J. E. 1975 DNA modification mechanisms and gene activity during development. Science 187, 226-232.

Liskay R. M. and Evans R. J. 1980 Inactive X chromosome DNA does not function in DNA-mediated cell transformation for the hypoxanthine phosphoribosyltransferase gene. Proc. Natl. Acad. Sci. USA 77, 4895-4898.

Lyko F., Ramasahoye B. H. and Jaenisch R. 2000 DNA methylation in Drosophila melanogaster. Nature 408, 538-540.

Mohandas T., Sparkes R. S. and Shapiro L. J. 1981 Reactivation of an inactive human $\mathrm{X}$ chromosome: evidence for $\mathrm{X}$ inactivation by DNA methylation. Science 211, 393-396.

Rice P., Longden I. and Bleasby A. 2000 EMBOSS: the European Molecular Biology Open Software Suite. Trends Genet. 16, 276-277.

Riggs A. D. $1975 \mathrm{X}$ inactivation, differentiation and DNA methylation. Cytogenet. Cell Genet. 14, 9-25.

Sanger F., Coulson A. R., Friedmann T., Air G. M., Barrell B. G., Brown N. L., Fiddes J. C., Hutchison C. A. III, Slocombe P. M. and Smith M. 1978 The nucleotide sequence of bacteriophage phiX174. J. Mol Biol. 125, 225-246.

Woodcock D. M., Crowther P. J. and Diver W. P. 1987 The majority of methylated deoxycytidines in human DNA are not in the $\mathrm{CpG}$ dinucleotide. Biochem. Biophys. Res. Comm. 145, 888-894. 